\title{
Results from Magnetic Gradient Surveys at the Walnut Branch (41CE47), Ross I (41CE485), and Ross II (41CE486) Sites in Cherokee County, Texas
}

\author{
Duncan McKinnon \\ University of Central Arkansas \\ Kevin Stingley \\ Heritage Center of Cherokee County
}

Follow this and additional works at: https://scholarworks.sfasu.edu/ita

Part of the American Material Culture Commons, Archaeological Anthropology Commons, Environmental Studies Commons, Other American Studies Commons, Other Arts and Humanities Commons, Other History of Art, Architecture, and Archaeology Commons, and the United States History Commons

Tell us how this article helped you.

This Article is brought to you for free and open access by the Center for Regional Heritage Research at SFA ScholarWorks. It has been accepted for inclusion in Index of Texas Archaeology: Open Access Gray Literature from the Lone Star State by an authorized editor of SFA ScholarWorks. For more information, please contact cdsscholarworks@sfasu.edu. 
Results from Magnetic Gradient Surveys at the Walnut Branch (41CE47), Ross I (41CE485), and Ross II (41CE486) Sites in Cherokee County, Texas

\section{Creative Commons License}

\section{(c) (1) \&}

This work is licensed under a Creative Commons Attribution-NonCommercial 4.0 International License 


\title{
Results from Magnetic Gradient Surveys at the Walnut Branch (41CE47), Ross I (41CE485), and Ross II (41CE486) Sites in Cherokee County, Texas
}

\author{
Duncan P. McKinnon and Kevin Stingley
}

The use of magnetic gradient surveys at Caddo sites located throughout the Caddo people's ancestral lands within the current areas of East Texas, Southwest Arkansas, Northwest Louisiana, and eastern Oklahoma has been very successful in the elucidation and mapping of the distributional characteristics of buried cultural features (see Hammerstedt et al. 2010; McKinnon 2017; Perttula et al. 2008; Walker and McKinnon 2012). In March 2018, three Caddo sites in East Texas (41CE47, 41CE485, 41CE486) were surveyed and the results add to the growing corpus of remote sensing spatial data. The recent survey work was conducted in order to assess the nature of sub-surface preservation of archaeological deposits in different environmental and historical contexts and to map the distribution of geophysical anomalies attributed to the Caddo occupations. The following presents results and preliminary interpretations.

\section{Magnetic Gradient}

Magnetic gradient interpretations discussed herein are developed using a combination of inductive and deductive approaches. An inductive approach has roots in satellite and aerial image interpretation with the recognition that geometric shapes, relative sizes, and systematic repetitions of image objects can form interpretable patterns (Wilson 2000). When anomalies in a geophysical dataset resemble patterns of regular geometric shapes, it can be induced that they are of probable cultural origin. A deductive approach utilizes known physical properties of the subsurface matrix (artifacts, features, sediments, and soils recorded during excavations) to deduce how instrument sensors might respond, and thus certain interpretative deductions can be made about the nature of anomalies revealed in the data. For example, thermoremanent magnetism is the result of highly heated burning events, which can produce an anomaly composed of stronger magnetic values (see Kvamme 2006, 2008). Anomalies of medium to high magnetic value may be deduced as being generated by a hearth, kiln, or burned house, for example. A soil matrix that has been magnetically enriched through pedogenesis (induced magnetism and magnetic susceptibility) can also produce anomalies containing stronger magnetic values than those in the surrounding matrix (see Kvamme 2006, 2008). Several low to medium magnetic signatures identified within or around a structure may be deduced as being pits. The highest magnetic values are typically related to ferrous metal debris buried close to the surface, which can generate anomalies of extreme magnitude. Magnetic values collected by magnetic gradient instruments are recorded in nanotesla (nT; $10^{9}$ tesla).

The magnetic gradient surveys discussed in this article were conducted using a Bartington Grad 6012 fluxgate gradiometer (Bartington and Chapman 2004). The Grad 601-2 is a vertical component fluxgate gradiometer containing two cylindrical sensor assemblies. Each cylindrical sensor assembly contains two mounted sensors with a 1 meter vertical spatial separation that measure the vertical component of the magnetic field. Since magnetic strength decreases with the cube of distance $\left(1 / \mathrm{d}^{3}\right)$, the lower sensor is more sensitive to subsurface readings whereas the opposite upper sensor is more sensitive to Earth's magnetic field (Clark 1996:78). Simple differencing of the two readings removes the effects of the latter. Given that the Bartington instrument offers a vertical sensor separation of 1 meter, the sensitivity of the instrument is greatly increased, and subsurface magnetic features more pronounced, when compared to gradiometers with a shorter sensor separation (Bartington and Chapman 2004). 
Data at all three sites were collected within established 20 × 20 meter grids where a survey tape was pulled taut along each baseline and non-metallic pin flags were placed along baselines to guide the surveyor (Figure 1). White non-metallic pin flags were set at every odd meter with a blue nonmetallic pin flag set on every fifth meter. The established non-metallic pin flags were used as transect (Y) collection guidelines in order to maintain 0.5 meter spacing along each grid baseline (X). Collection spacing along each transect $(\mathrm{Y})$ was set to 0.125 meter spacing (8 samples per meter) and regulated using a focused and practiced walking pace of 1.3 meters/second. Data were collected using a zigzag pattern.

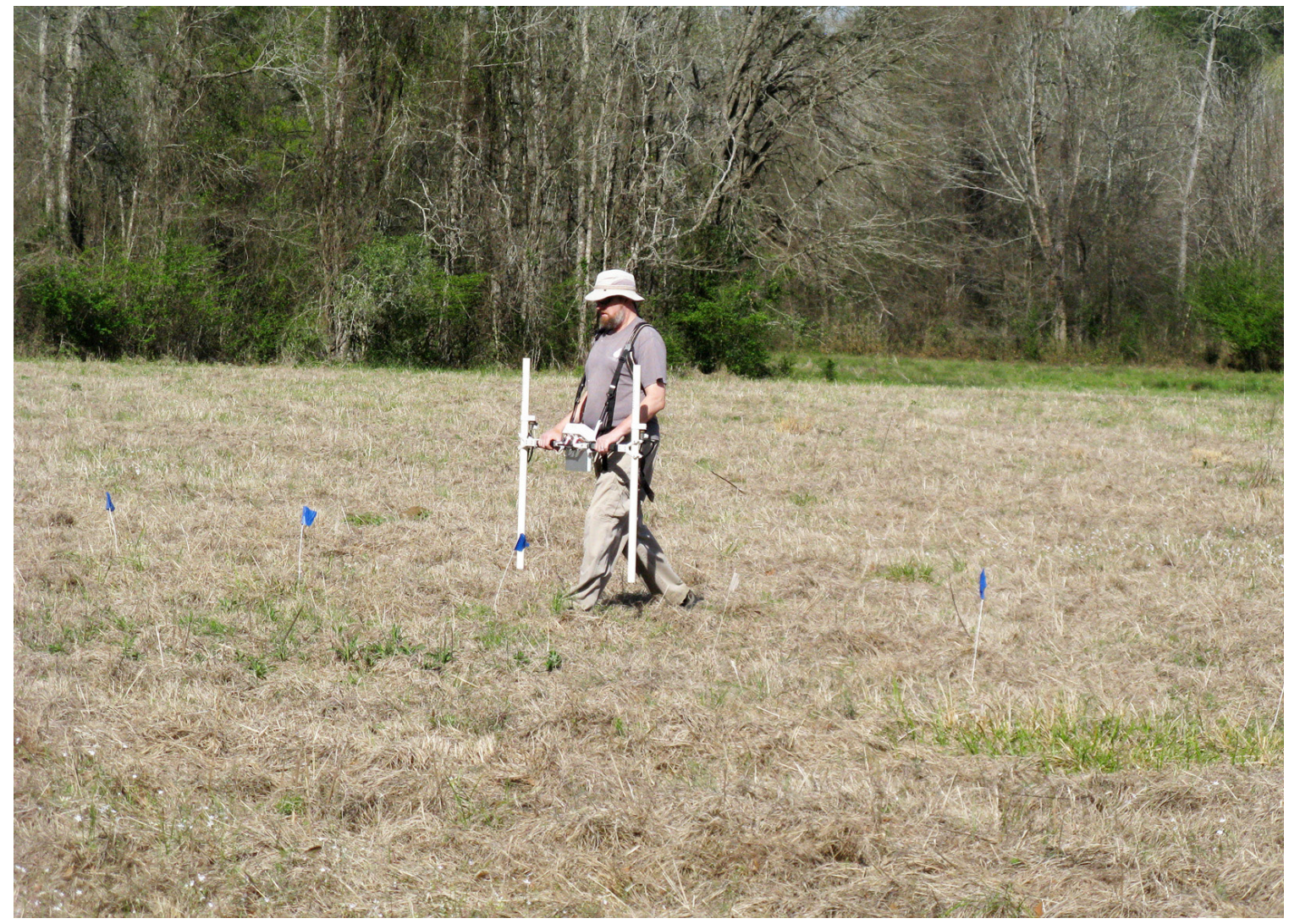

Figure 1. Data collection at Walnut Branch (41CE47) was conducted using a Bartington Grad 601-2 fluxgate gradiometer. White and blue non-metallic pin flags were used to guide the surveyor.

\section{Magnetic Gradient Survey Results}

The magnetic gradient survey work was conducted from March 19 to 21, 2018, at three Caddo sites in Cherokee County southwest of Rusk, Texas (Figure 2). Recent analyses of artifacts collected from the sites during surface collections and intensive shovel testing demonstrate that Ross I (41CE485) site was in use during the later periods of the Frankston phase (A.D. 1400-1680) and that all three sites represent a Historic Caddo community that was in use during the Historic Caddo Allen phase (post-ca. A.D. 1680) (Perttula and Stingley 2017a).

The three sites are closely spaced and situated within a pastured floodplain along Walnut Branch in the Box Creek drainage (Figure 3). Box Creek flows to the southeast and drains into the Neches River roughly $20 \mathrm{~km}$ to the southwest, and not far from where Bowles Creek empties into the Neches (see McKinnon 2017; Perttula and Stingley 2016a, 2016b, 2017b). Box Creeks is only a few kilometers southwest of the George C. Davis site (41CE19), also known as Caddo Mounds State Historic Site (see Newell and Krieger 2000). 


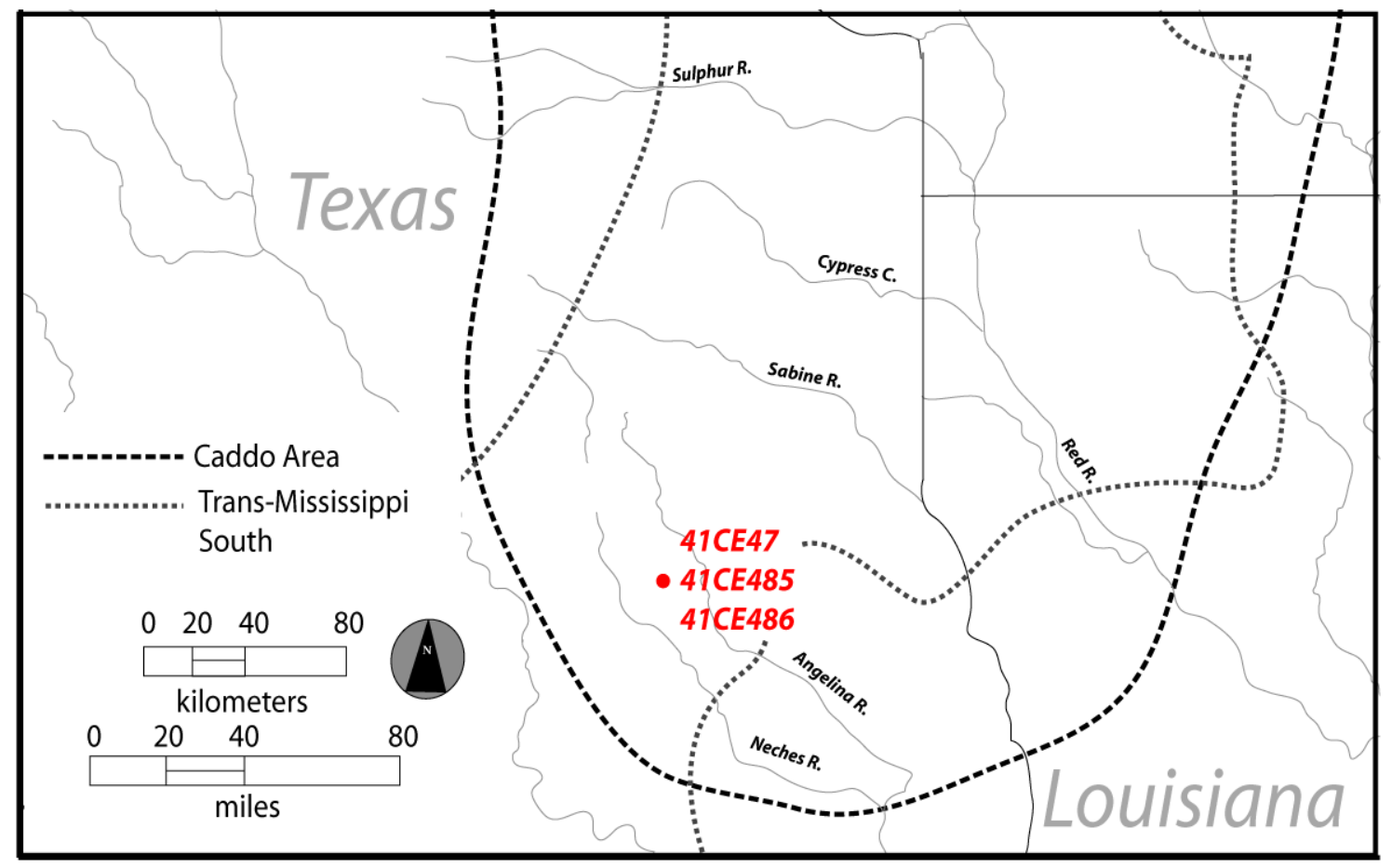

Figure 2. The Caddo Archaeological Area with the general location of the three surveyed sites within the Neches River drainage.

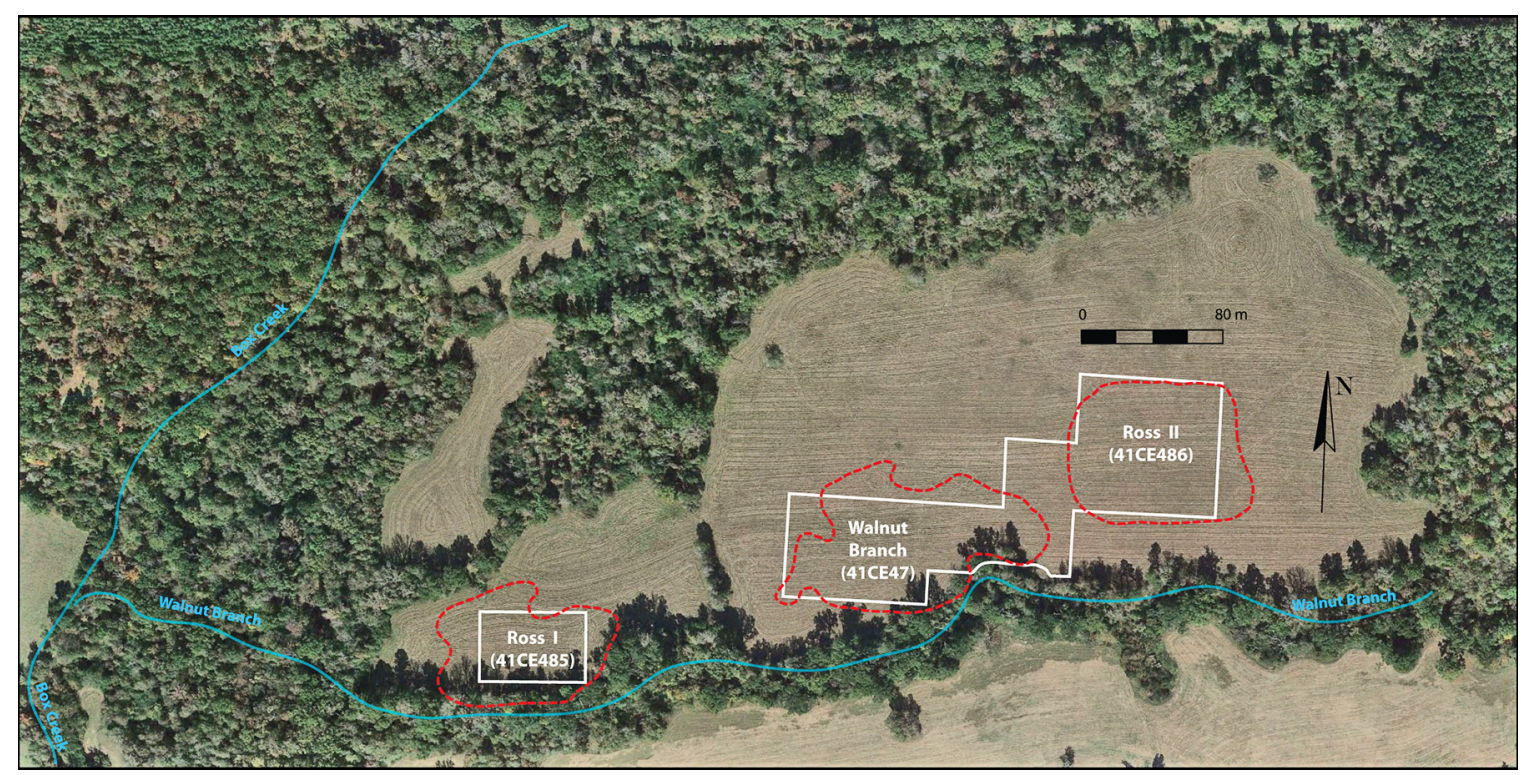

Figure 3. The location of the Walnut Branch (CE47), Ross I (CE485), and Ross II (CE486) sites along Walnut Branch. White boundary represents area surveyed using magnetic gradient. Red dotted lines represent the estimated site boundaries established during surface collections and shovel testing (Perttula and Stingley 2017a:Figures 4, 6, 8). 
At the three sites, $4620 \times 20$ meter grids (1.84 ha) were established in areas of the site that contained high densities, or clusters, of artifacts that suggest they are the location of Caddo farmstead compounds (Perttula and Stingley 2017a). In order to conform to the landscape along Walnut Branch and estimated site limits, grids in CE47 (Walnut Branch) and CE486 (Ross II) were established a few degrees east of north.

\section{Walnut Branch (41CE47) and Ross II (41CE486)}

The Walnut Branch and Ross II sites are situated within a floodplain pasture on the north side of Walnut Branch. The landscape gradually slopes to the northeast with the Ross II site on a low topographic rise. Reports from the landowners state that during heavy rains, much of the pasture is flooded with the Ross II low rise usually not impacted. Magnetic gradient coverage at the Walnut Branch site is 2020 x 20 meter grids at approximately 8000 square meters (1.97 acres). Magnetic gradient coverage at the Ross II site is 1620 x 20 meter grids, or 6400 square meters (1.6 acres) (Figure 4).

Anomalies detected at both the Walnut Branch and Ross II sites were categorized based on $\mathrm{nT}$ values of $<1 \mathrm{nT}$ and $<1 \mathrm{nT}$. Results reveal dense concentrations of higher magnetic anomalies within the proposed boundaries of the two sites (Figure 5). At the Ross II site, higher magnetic anomalies are situated throughout the area with more dense concentrations in the grids to the northeast and on a low topographic rise. At the Walnut Branch site, higher magnetic anomalies are concentrated to the south, which is close to the Walnut Branch tributary. Between the two sites is a lack of higher magnetic anomalies that corresponds with previous shovel test work that demonstrates a lack of artifacts in this area (Perttula and Stingley 2017a).

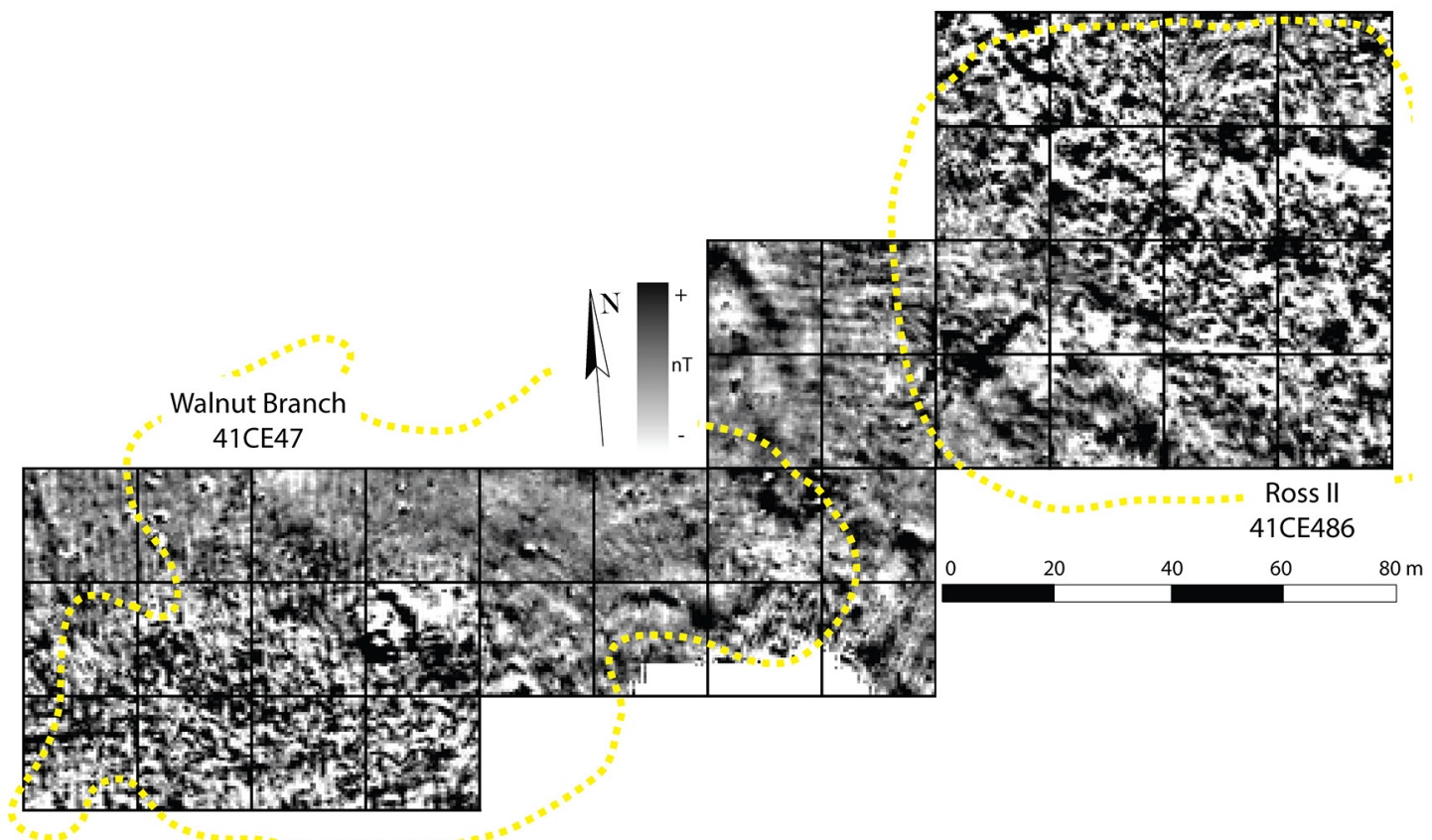

Figure 4. Magnetic gradient survey from the Walnut Branch and Ross II sites long Walnut Branch. The yellow dotted lines represent the estimated site boundaries established during surface collections and shovel testing (Perttula and Stingley 2017a:Figures 4 and 8). 


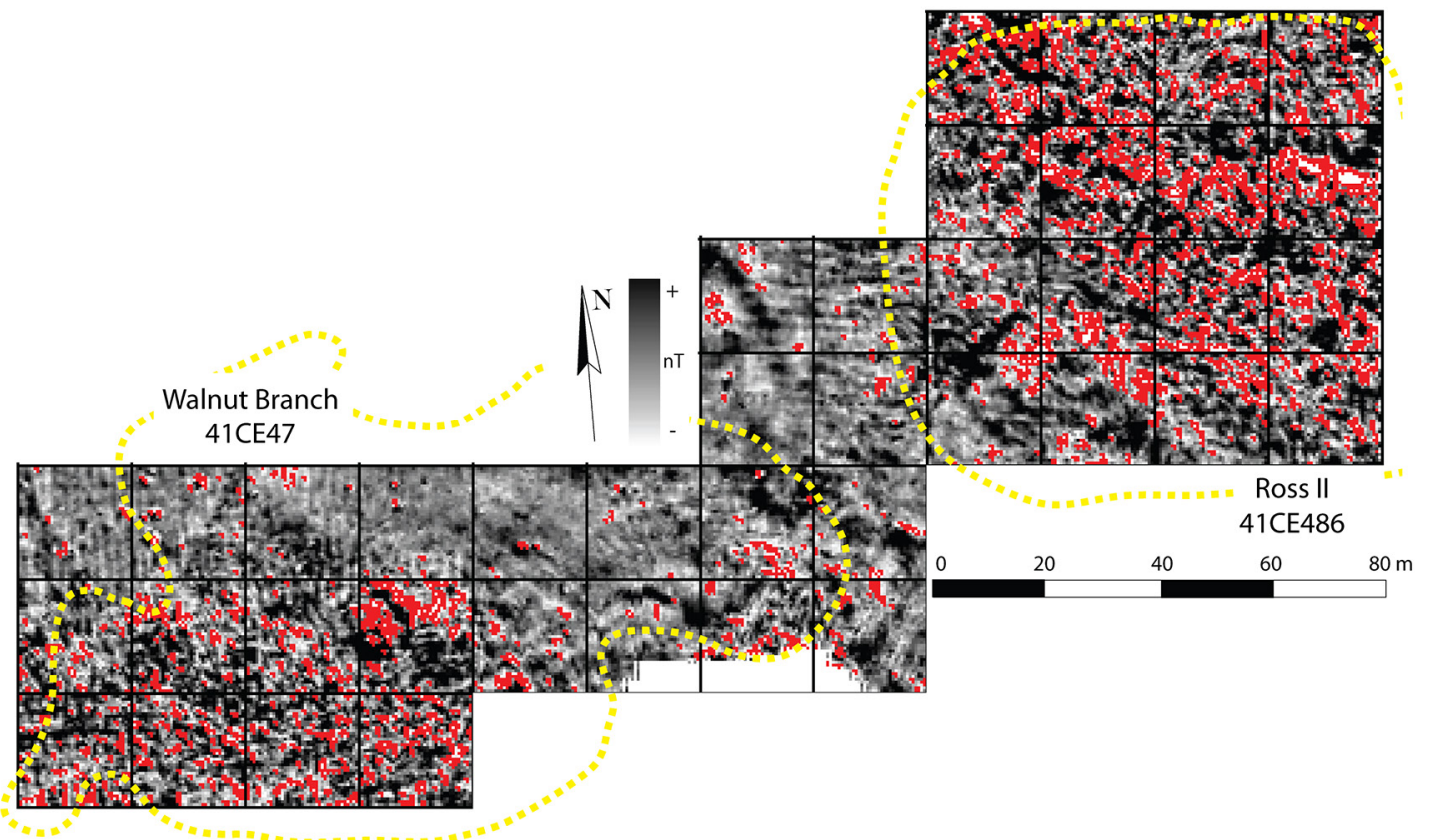

Figure 5. Higher magnetism clusters that correspond to the estimated site limits of the Walnut Branch and Ross II sites. An area of lower magnetic values is present between the two sites.

Within the Walnut Branch site area the remains of one or possibly two Caddo structures are suggested by the magnetic gradient data (Figure 6). Both proposed structures are located within the higher magnetic concentrations and on the boundaries of shovel test Artifact Cluster A.

Within the Ross II site area, anomalies are fairly random and abundant. The architectural remains of a single possible structure are suggested in the center of the survey area (Figure 7). The proposed structure is located between the boundaries of shovel test Artifact Cluster A and Cluster B. Interestingly, the proposed structure is defined by an absence of higher magnetism (see Figure 5), which suggests a cleaned internal floor devoid of artifact debris.

\section{Ross I (41CE485) site}

The Ross I site is within a neighboring pasture to the west of the Walnut Branch and Ross II sites (see Figure 2). The landscape is at a lower elevation that floods regularly. During the survey, there was evidence of recent flooding with tree and grass debris clustered throughout the area. Magnetic gradient coverage at the Ross I site is a small $60 \times 40$ meter area, 2400 square meters ( 0.59 acres), that was surveyed to test for the presence of architectural features (Figure 8).

Anomalies are fairly random across the Ross I site, many of which likely represent the movement of soil through flooding. There are three high magnetic anomalies that are in a line and likely represent the remains of a buried t-post from an old fence. Despite the randomness of anomalies, three possible structural features are interpreted based on pattern recognition (Figure 9). A single anomaly feature is interpreted within the Cluster B area as a series of higher magnetic readings that form a half circle about $5 \mathrm{~m}$ in diameter. Two additional anomaly features are interpreted between Cluster B and C in an area that has not been shovel tested. Both are approximately $5 \mathrm{~m}$ in diameter with a central anomaly, which is interpreted as a central hearth or pit to a Caddo structure. 

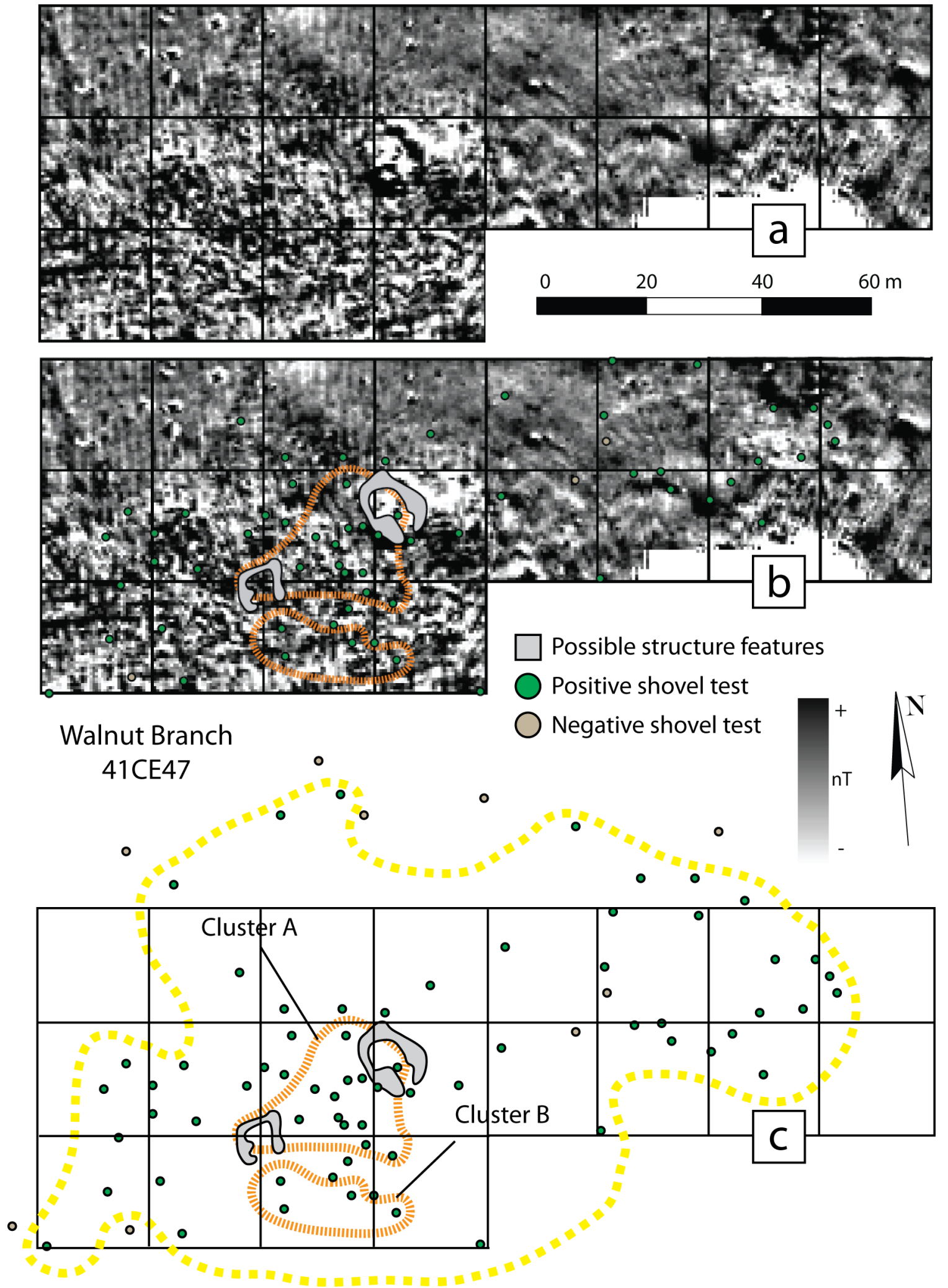

Figure 6. Walnut Branch site: (a) magnetic gradient results, (b) interpretations overlain on shovel test data and artifact cluster areas, (c) relationship of interpretations, site boundaries, artifact cluster areas, and shovel test locations with magnetic gradient results removed. 

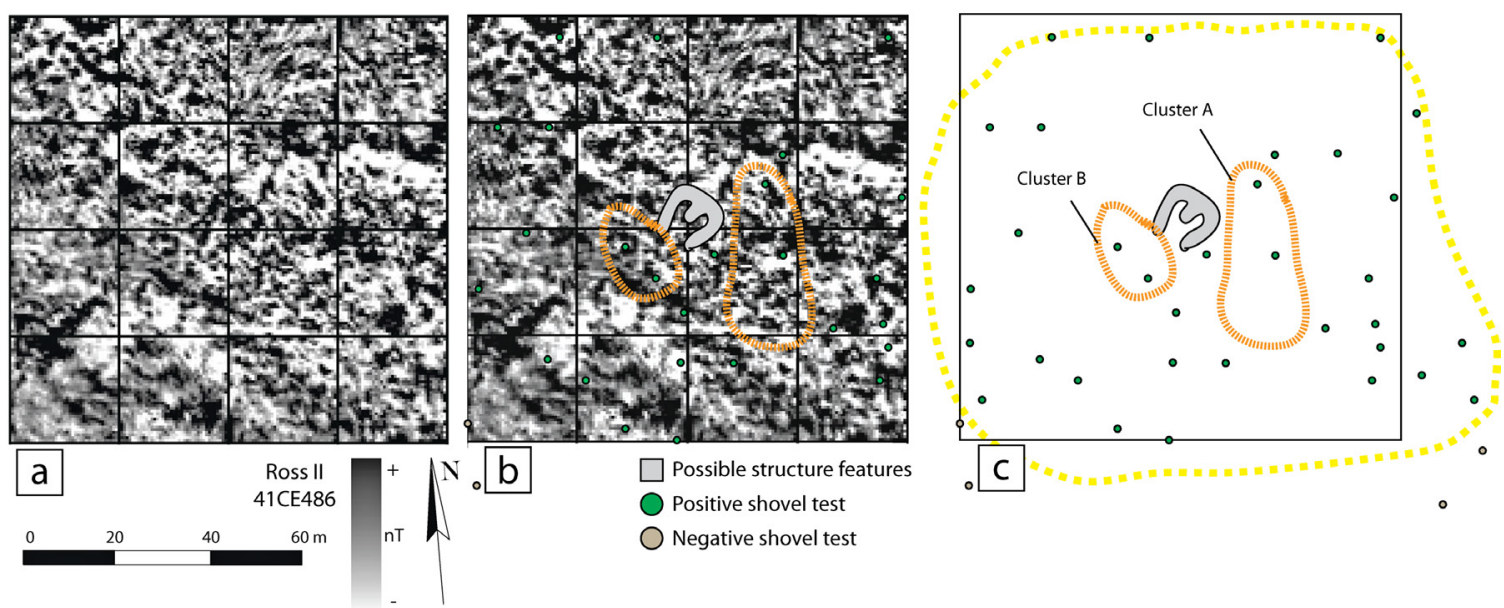

Figure 7. Ross II site: (a) magnetic gradient results, (b) interpretations overlain on shovel test data and artifact cluster areas, (c) relationship of interpretations, site boundaries, artifact cluster areas, and shovel test locations with magnetic gradient results removed.

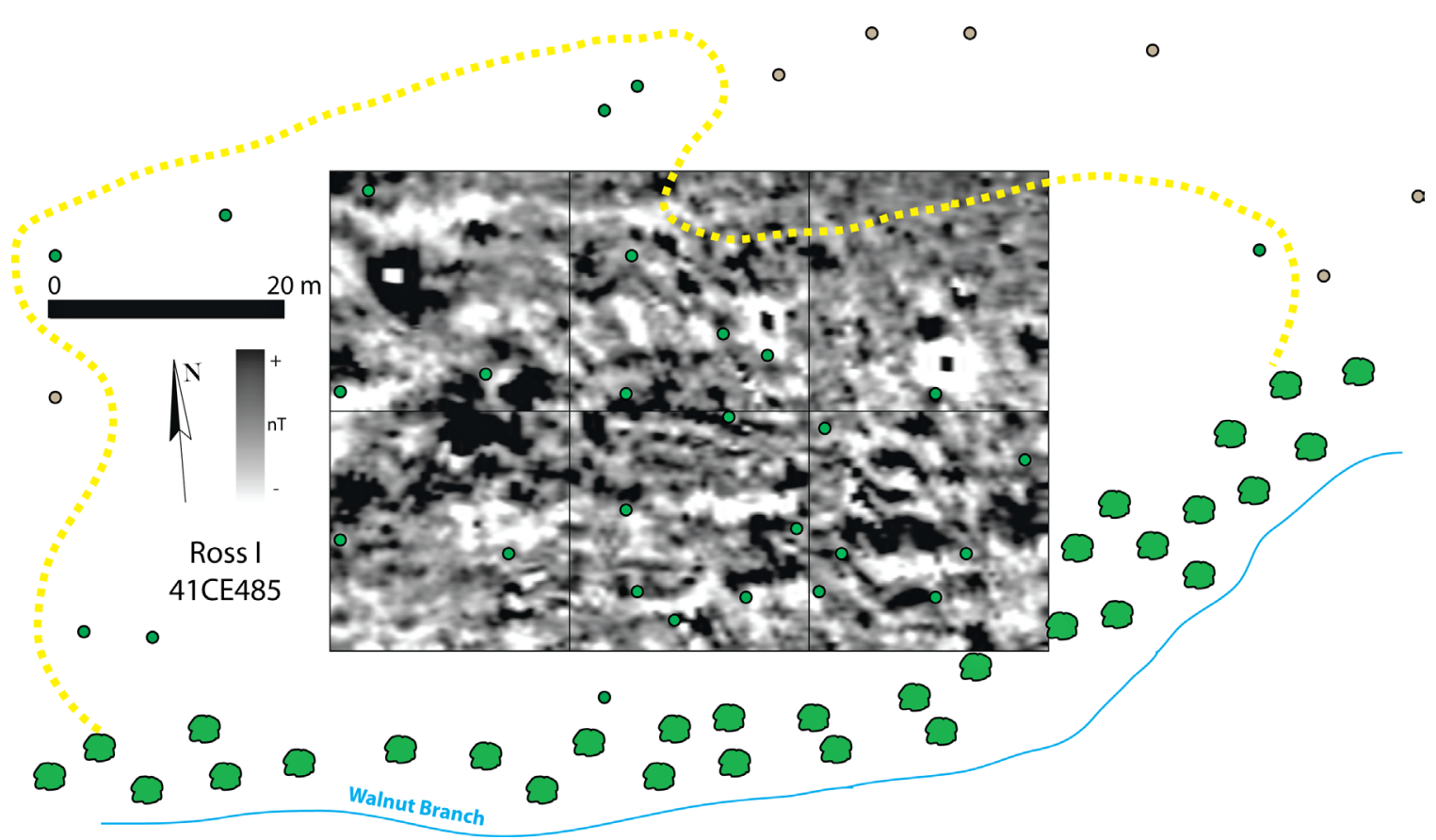

Figure 8. Magnetic gradient survey from the Ross I site along Walnut Branch. The yellow dotted line represents the estimated site boundary established during surface collections and shovel testing (Perttula and Stingley 2017a:Figure 6). 

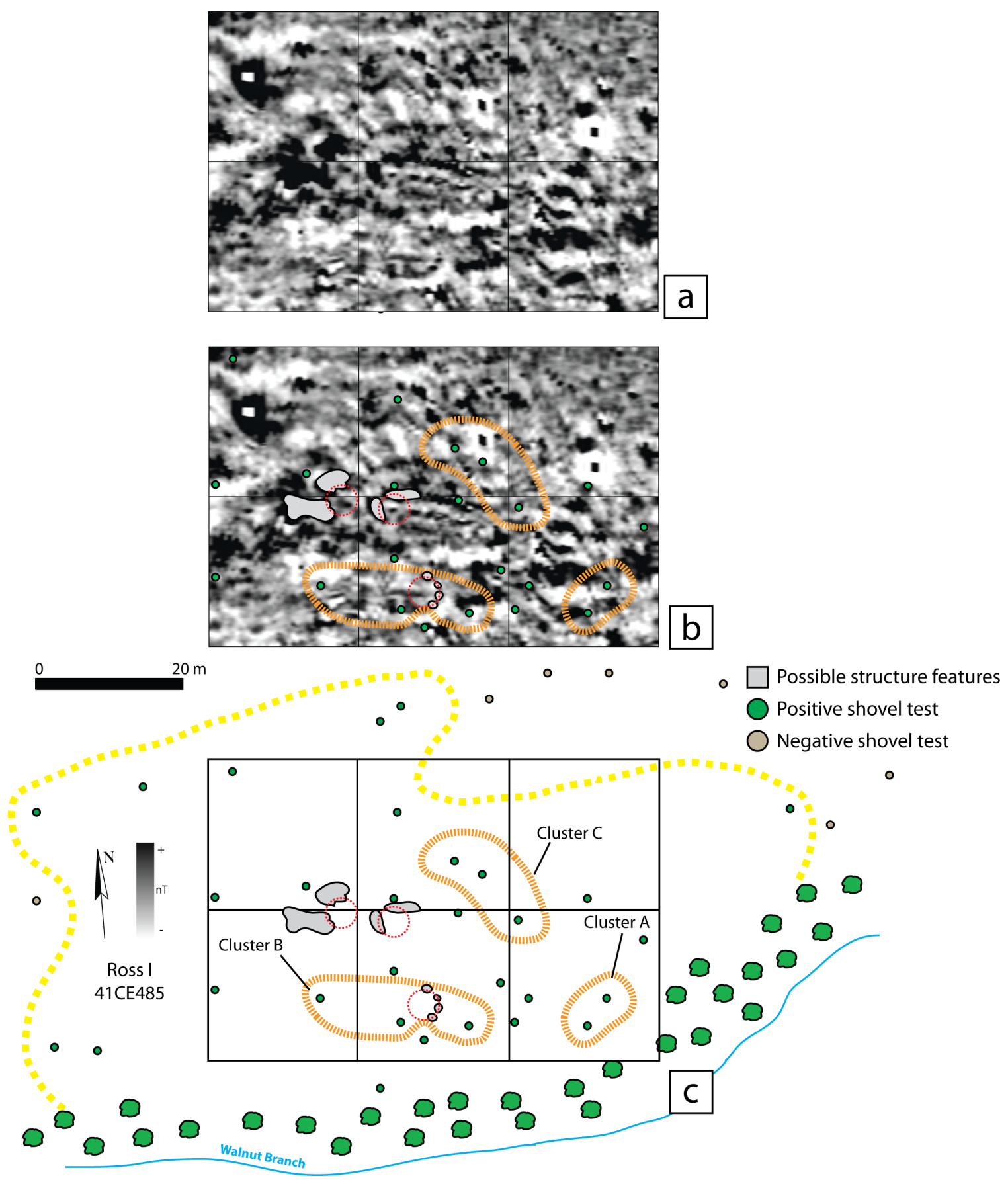

Figure 9. Ross I site: (a) magnetic gradient results, (b) interpretations overlain on shovel test data and artifact cluster areas, and (c) relationship of interpretations, site boundaries, artifact cluster areas, and shovel test locations with magnetic gradient removed. 


\section{Summary and Conclusions}

Results from the three separate yet related magnetic gradient surveys further demonstrate the value of using terrestrial-based remote sensing to document and map distributional characteristics of buried cultural features (Perttula et al. 2008). Interpretations suggest the location of the remains of several possible Caddo structures that likely are associated with a Historic Caddo community in use during the Historic Caddo Allen phase (post-ca. A.D. 1680) (Perttula and Stingley 2017a).

At the Walnut Branch (41CE47) and Ross II (41CE486) sites, clearly defined densities of higher magnetic anomalies correspond with artifact distributions and the establishment of site boundaries. Two possible structures are interpreted as present at the Walnut Branch site and are located within higher magnetic concentrations and on the boundaries of shovel test Artifact Cluster A. A single possible structure is interpreted at the Ross II site, which is centered within the survey area and between the Cluster A and B artifact concentrations. The Ross II structure is suggested as having a cleaned floor prior to abandonment. Finally, at the Ross I site (41CE485), several anomalies are interpreted as the remains of structural features, largely based on pattern recognition. The magnetic gradient results discussed will be integrated into a continued program of shovel testing and excavation units at the Walnut Branch and Ross I and II sites. With this integration of comparative datasets, we anticipate a further understanding of landscape use and occupation by the Caddo people who lived along Walnut Branch in the late seventeenth century.

\section{Acknowledgements}

Funding to support this survey work was provided by Archeological \& Environmental Consultants, LLC and by a grant from the Texas Archeological Society's Research Support Fund.

\section{References Cited}

Bartington, Geoff and Cyril E. Chapman

2004 A High-stability Fluxgate Magnetic Gradiometer for Shallow Geophysical Survey Applications. Archaeological Prospection 11:19-34.

Clark, Anthony

1996 Seeing Beneath the Soil: Prospecting Methods in Archaeology (New Edition). Revised Edition. B. T. Batsford Ltd., London.

Hammerstedt, Scott W., Amanda L. Regnier, and Patrick C. Livingood

2010 Geophysical and Archaeological Investigations at the Clement Site, A Caddo Mound Complex in Southeastern Oklahoma. Southeastern Archaeology 29(2):279-291.

Kvamme, Kenneth L.

2006 Magnetometry: Nature's Gift to Archaeology. In Remote Sensing in Archaeology, An Explicitly North American Perspective, edited by Jay K. Johnson, pp. 205-233. University of Alabama Press, Tuscaloosa, Alabama.

2008 Remote Sensing Approaches to Archaeological Reasoning: Pattern Recognition and Physical Principles. In Archaeological Concepts for the Study of the Cultural Past, edited by Alan P. Sullivan, pp. 65-84. The University of Utah Press, Salt Lake City.

McKinnon, Duncan P.

2017 Report on Magnetic Gradiometry Survey at Three Caddo Sites in East Texas. Journal of Northeast Texas Archaeology 72:169-175. 
Newell, H. Perry and Alex D. Krieger

2000 The George C. Davis Site, Cherokee County, Texas. 2nd Edition. Society for American Archaeology, Washington, D.C.

Perttula, Timothy K., Chester P. Walker, and T. Clay Schultz

2008 A Revolution in Caddo Archaeology: The Remote Sensing and Archaeological View from the Hill Farm Site (41BW169) in Bowie County, Texas. Southeastern Archaeology 27(1):93-107.

Perttula, Timothy K. and Kevin Stingley

2016a Additional Material Culture Remains from the Bowles Creek Site (41CE475) in Cherokee County, Texas. Journal of Northeast Texas Archaeology 67:7-14

2016b Analysis of the Recovered Artifacts from the Controlled Surface Collection at the Peach Orchard Site (41CE477), Cherokee County, Texas. Journal of Northeast Texas Archaeology 70:91-110.

2017a Archaeological Investigations at the Walnut Branch (41CE47), Ross I (41CE485), and Ross II (41CE486) Sites, Cherokee County, Texas. Journal of Northeast Texas Archaeology 76:31-70.

2017b Renewed Archaeological Investigations at the Bowles Creek (41CE475), Cornfield (41CE476), and Peach Orchard (41CE477) Sites in the Bowles Creek Valley, Cherokee County, Texas. Journal of Northeast Texas Archaeology 71:1-24.

Wilson, David R.

2000 Air Photo Interpretation for Archaeologists. St. Martin’s Press, New York. 